\title{
Creative attitude in a group of youths gifted in the domain of science subjects
}

\author{
Monika Sztolpa $a^{A, B, C, D, E, F, G}$, Aleksandra Lewandowska-Walter ${ }^{C, D, E}$, Matgorzata Lipowska ${ }^{D, E, F}$ \\ Institute of Psychology, University of Gdansk, Gdansk, Poland
}

\section{BACKGROUND}

We attempted to assess whether students identified by their teachers as gifted in the domain of science are characterised by significantly higher levels of intelligence and creativity than other students. We investigated the features of their personalities that are indicators of their exhibited creative or reproductive attitude in the cognitive and the motivational domains. As a consequence, criteria will be developed for identifying gifted students.

\section{PARTICIPANTS AND PROCEDURE}

Ninety-seven students, aged 13-17, took part in the study. The students were previously identified by their teachers as gifted. Levels of intellectual functioning were assessed using a battery of tests for diagnosing intelligence (APIS-P) and Raven's Standard Progressive Matrices (SPM). Creativity was estimated using the Test for Creative Thinking - Drawing Production (TCT-DP), and creative attitude was assessed using the KANH questionnaire.

\section{RESULTS}

Analysis of the results revealed that students nominated by their teachers scored significantly higher than their peers in general intelligence and creativity tests. Moreover, they were characterised by a more frequent choice of heuristic behaviours in the cognitive domain and nonconformity in the motivational domain. Additionally, there was a statistical trend a general creative attitude among the nominated students.

\section{CONCLUSIONS}

We found that gifted students scored high on general intelligence and creativity tests. Consistency between the teachers' nominations and our results indicates that the criteria for identifying gifted students are appropriate. Moreover, instructing teachers about a creative attitude helped them to also identify gifted students with higher levels of nonconformity and who create their own heuristics for behaviour. These characteristics are valuable for innovative activity, which is what programmes for gifted students try to encourage.

KEY WORDS

creativity; gifted student; nonconformity; heuristic behaviour; identifying talents

CORRESPONDING Author - Monika Sztolpa, Institute of Psychology, University of Gdansk, 4 Bażyńskiego Str., 80-952 Gdansk, Poland, e-mail: monikasztolpa@gmail.com

Authors' contribution - A: Study design · B: Data collection · C: Statistical analysis · D: Data interpretation ·

E: Manuscript preparation · F: Literature search · G: Funds collection

to CITE this ARTICLE - Sztolpa, M., Lewandowska-Walter, A., \& Lipowska, M. (2016). Creative attitude in a group

of youths gifted in the domain of science subjects. Current Issues in Personality Psychology, 4(2), 97-105.

RECEIVED 11.03.2016 · REVIEWED 31.03.2016 · ACCEPTED 15.04.2016 · PUBLISHED 06.05.2016 


\section{BACKGROUND}

\section{THE CONCEPT OF GIFTEDNESS}

The issue of giftedness - its genesis, structure, and underlying mechanisms - is of interest to many theorists and practitioners. Many conceptions and models of giftedness have emerged as a result of research. Models of general giftedness usually equate giftedness with general intelligence (Gardner, 2002; Kaufman \& Sternberg, 2008; Nęcka, 2003; Sternberg \& Davidson, 2005; Ziegler \& Heller, 2000) or multiple intelligences (Gardner, 1983, 2002). On the other hand, the domain-specific conception of giftedness assumes that the development of a person is associated with many domains and areas of activity (Limont, 2012; Rinn \& Plucker, 2004; Tannenbaum, 2003), due to which talents may develop even in narrow domains. Again, systemic models treat giftedness as a structure of elements that are interconnected and interact with each other (Freeman, 2010; Limont, 2012; Saha, 2012; Sękowski, 2013). Such elements include cognitive abilities, directional skills, creativity, personality and motivation to undertake an activity.

\section{The tree-ring conception of giftedness}

One of the more interesting and frequently used systemic conceptions of giftedness is the tree-ring conception of giftedness developed by Renzulli (Renzulli, 1978; Renzulli \& Reis, 2000), which serves as the basis of the present study. The author, and the researchers who would later further develop the model, assume that when identifying an individual as gifted, one needs to take into account all of the included elements. The first ring describes characteristics that are associated with being absorbed in an activity or task (Renzulli, 1978), understood as motivation to undertake an activity (Mönks, 2008; Rinn, 2012; Subotnik, Olszewski-Kubilius, \& Worrell, 2011), deep concentration on the task, and a state of extraordinary engagement and forgetting oneself - having flow (Csikszentmihalyi, 1996), or striving for excellence and feeling positive emotions in task situations perceived as challenges.

Above-average general giftedness, understood either as high intellectual potential (based on the results of intelligence tests), which has particular importance in the process of learning at school and drawing conclusions (Nęcka, 2003; Pfeiffer, 2012; Reis \& McCoach, 2000), or as specific directional talents, which may appear in all possible disciplines (Limont, 2012; Lohman, 2005; Worrell, Olszewski-Kubilius, \& Subotnik, 2012), is an important element of the model. The third ring of the model includes general creativity, which is currently considered in terms of fluency, elasticity and originality of thinking (Amabile, 1996; Guil- ford, 1978; Nęcka, 2002), openness to new experiences, cognitive curiosity (Strzałecki, 2003), preference for risk in thinking and acting, attention to detail and feelings (Lewis, 1998), focusing on finding a solution, elasticity in combining data and elaboration (Urban, 1996, 2000, cf: Matczak, Jaworowska, \& Stańczak, 2000).

\section{Multifactor Model}

The Multifactor Model of giftedness by Franz J. Mönks (1990) is an extension of the above model. Mönks concluded that a person excelling is always the result of the aforementioned elements and the influence of the student's social environment (family, peers, school), which may both stimulate and inhibit the development of talents (Popek, 2001; Ziegler \& Heller, 2000) and personality (Dyrda, 2000; Freiman, 2006; Siekańska \& Sękowski, 2008). In terms of personality, creative behaviours and attitudes are believed to play a significant role (Maslow, 1983; Mumford, Scott, Gaddis, \& Strange, 2002; Popek, 2008), assuming interplay between the motivational-emotional and cognitive functions (Popek, 2008, Subotnik et al., 2011). According to research, individuals characterised by such an attitude are independent, introverted, subjective and maladapted in terms of psychological definitions, but well adapted to work and socially valuable (Strzałecki, 2003). Moreover, they are characterised by specific attributes of social adaptation as well as by constructive nonconformity (Popek, 2001).

\section{GIFTED STUDENTS}

Gifted students are also characterised by specific cognitive and personality properties. Their broad knowledge and intelligence (Pfeiffer, 2012; Reis \& McCoach, 2000), directional talents and interests (Lohman, 2005; Worrell et al., 2012) as well as creativity (Limont, 2012; Popek, 2001) are often mentioned. Emotional-motivational features are also important (Gottfried, Gottfried, Cook \& Morris, 2005; Rinn, 2012). Such students show initiative and originality in their intellectual work, are inquisitive, have an independent attitude and take risks to pursue their passions (Subotnik et al., 2011). They also have the ability to defend their beliefs and ideas (Dyrda, 2000; Limont, 2012).

Research also provides data about characteristics in the area of creative attitude, especially the domain of motivation (defined on the conformity-nonconformity continuum) and the role of teachers in its development (Sokol, Gozdek, \& Figurska, 2015). A non-conforming student exhibits independent thinking and acting (based on their own system of values), they bravely take on cognitive and social challenges, and they have positive personality energy that stimulates their potential activity in the cognitive domain as well as their behaviour (Bernacka \& Misiuda-Kolejko, 2008; Popek, 
2001, 2008). In contrast, a conformist has a tendency towards submissiveness to expectations and external pressures, and adapts their behaviour and way of thinking to the expected standards, which hinders their activity in both the cognitive and the behavioural domains (Bernacka, 2008).

Students exhibiting talents in the area of science are diverse, and so an individual approach is necessary in their education (Bicknell, 2009). They often show early cognitive curiosity, the ability to generalise, a facility with numbers, and the ability to discover logical principles (Wieczerkowski, Cropley, $\&$ Prado, 2000). They are shown to be able to shorten the inference process as well as possessing elasticity and flexibility (the ability to switch between operations) of mental processes, and ability in symbolic thinking (Diezmann \& Watters, 2000). The skill of creative reasoning has also been observed (Renzulli, 2005), although it does not fully correspond to creativity in other disciplines, due to the nature of science subjects (Milgram \& Livne, 2005, in: Chamberlin \& Moon, 2005). Such students often seek the most economic solutions, develop their own heuristics, and quickly see schemata and relationships between objects (Chamberlin \& Moon, 2005; Miller, 1990); they are fast learners and are quick to understand tasks. In terms of personality, they exhibit lower levels of anxiety (Saricam \& Ogurlu, 2015), they have a tendency for critical thinking and non-conformism, and their self-regulation abilities are better (Tortop, 2015).

\section{IDENTIFYING TALENTS IN STUDENTS}

It is believed that teachers have a particular role in the process of identifying talents or giftedness (Renzulli \& Reiss, 2000). Reviewing the literature shows that there is no single criterion according to which one can qualify a student as gifted (Cieślikowska, 2008; Tokarz, 2005), and no single feature is a clear indicator of giftedness. Students are mainly distinguished by their scores on intelligence tests (Callahan, Moon, \& Oh, 2013; Deary, Strand, Smith, \& Fernandes, 2007; Gottfried, Gottfried, Bathurst, \& Guerin, 1994). Specific personality features and behaviours of a student are taken into account (Limont, 2012; Popek, 2001). An often-used approach to identify gifted students is to think in terms of the interactional nature of talents, including creativity (Morgan, Latham, \& Shifflet, 2009; Ledzińska, 2010; Limont, 2012; Sękowski, 2013; Renzulli, 2005). Moreover, it has been shown that talents must be analysed in the context of actual cultural background (Csikszentmihalyi \& Robinson, 1990; Szymanski \& Shaff, 2013). Ledzińska (2010) proposed a holistic approach to identifying gifted individuals, which takes into account both the external environment that constitutes the context for talent development as well as the richness of the internal environment.
This study attempted to assess whether students identified by their teachers as gifted in the domain of science are indeed characterised by higher intelligence and creativity than other students. Moreover, we investigated their personality features, which are an indicator of their attitude - creative or reproductive - in the cognitive and motivational spheres. Identification as gifted would qualify students for further forms of systemic support within the "Zdolni z Pomorza" (Polish for: The Talented from the Pomeranian Region) programme ${ }^{1}$.

\section{PARTICIPANTS AND PROCEDURE}

\section{PARTICIPANTS}

Ninety-seven secondary school students took part in the study - 32 girls and 65 boys aged between 13 and $17(M=15.79, S D=1.24)$. There were no gender differences in terms of level of education $\left(\chi^{2}(1)=.33\right.$, $p=.565, \varphi=.08)$.

\section{PROCEDURE AND MEASURES}

Students who were identified by their teachers as gifted in the areas of mathematics, informatics or physics were assessed. Teachers were given a twohour training session to prepare them to identify students gifted in the areas of mathematics, programming and physics, and were then asked to identify such students. Apart from cognitive skills and directional talents, the teachers' attention was brought to features such as innovativeness, undertaking additional activities and extracurricular classes as well as signs of creative thinking and creative attitude.

Two diagnostic methods were used to assess cognitive skills. The level of intellectual functioning was assessed using a battery of tests for diagnosing intelligence APIS-P (Matczak, Jaworowska, Ciechanowska, Stańczak, \& Zalewska, 2005), which allows the calculation of a general score that indicates the levels of crystallised intelligence, while taking into account the component skills: social skills, visuo-spatial skills, verbal skills and abstract-logical skills. In order to complement the diagnosis of intellectual potential, we also used Raven's Standard Progressive Matrices test (1991), which assesses the ability to reason correctly, relatively independently of experience, defined as the ability to infer about relations and to create non-verbal concepts based on perceptiveness and logical thinking.

The creativity of the students was assessed using Urban-Jellen's Test for Creative Thinking - Drawing Production (TCT-DP) (2000). The participants' creations were judged with regard to fluency, originality, the ability to elaborate and synthesize, nonconfor- 
mity, and readiness to take risks as well as sense of humour and emotional engagement.

The Creative Behaviour Questionnaire (KANH), adapted by Popek (2008) was used to identify a creative attitude, complementing the assessment of creativity with personality factors. The test assumes that a creative attitude is primarily composed of two domains of human functioning: cognitive and characterological. Within the cognitive domain, it suggests a broader approach than assessments made just in terms of IQ. Sensitivity and perceptivity, memory (mainly processing and producing new information), imagination, intuition and divergent thinking are also taken into account. Based on their responses, a subject is qualified as exhibiting algorithmic (reconstructive attitude) or heuristic (creative attitude) behaviours. On the other hand, the characterological domain is a set of features that ensure the fulfilment of potential capabilities, considered in two dimensions: conformism (a characteristic of the non-creative attitude) and non-conformism (characteristic of the creative attitude).

\section{RESULTS}

The first analysis served to answer the question of whether students nominated by their teachers are characterised by above-average levels of intelligence and creativity (relative to the population of students). In order to answer this question, we conducted a one-sample $t$-test comparing the mean score in the sample to the population average (5.50). The results are presented in Table 1 . The analysis revealed that students nominated by their teachers had significantly higher scores for general intelligence $(t(96)=11.72$, $p<.001)$ and creativity $(t(96)=10.73, p<.001)$ when compared to the average for this population.
Next we checked whether different character features comprising the creative and reconstructive attitudes differentiate the nominated students from the general population. The results of the analysis suggest that, in comparison to the general population, students identified as gifted rank higher in the cognitive domain $(t(96)=3.81, p<.001)$. They exhibit significantly more heuristic type behaviours in this domain $(t(96)=3.89, p<.001)$. Higher than average results were also observed in the motivational domain $(t(96)=2.36, p=.001)$, both in terms of nonconformity and conformity.

As there was substantial variability in the results of the students nominated by their teachers in the tests assessing their intellectual potential, we subdivided them into two groups based on these results: those that scored high on tests assessing general intelligence and those with average scores. Subsequent analysis investigated whether these two groups of students differ in the personality features that are indicators of a creative attitude (Table 2).

The results indicate that students who scored high in the general intelligence test are characterised by a more creative attitude $(t(95)=-2.55, p=.012)$ within the cognitive domain $(t(95)=-2.65, p=.009)$ and the motivational domain $(t(95)=-3.14, p=.002)$. They choose heuristic behaviours more often $(t(95)=-2.58, p=.011)$ and are characterised by greater nonconformism $(t(95)=-2.60, p=.011)$.

The level of creativity was also used as a differentiating factor, and it was investigated whether it differentiates the students in terms of the same features (Table 3). However, no significant differences were observed here.

The next stage was to verify whether students qualified to receive further forms of talent support are characterised by higher levels of creativity and

Table 1

Levels of intelligence and creativity, and personality features of students in the investigated sample

\begin{tabular}{|c|c|c|c|c|}
\hline & M & $S D$ & $t(96)$ & $p$ \\
\hline TMS Raven & 92.71 & 12.67 & 33.21 & $<.001$ \\
\hline APIS-P & 7.67 & 1.82 & 11.72 & $<.001$ \\
\hline TCT-DP & 7.53 & 1.86 & 10.73 & $<.001$ \\
\hline Conformism & 5.18 & 1.85 & -1.73 & .043 \\
\hline Nonconformism & 5.92 & 2.34 & 1.76 & .040 \\
\hline Heuristic behaviours & 6.36 & 2.18 & 3.89 & $<.001$ \\
\hline Algorithmic behaviours & 5.06 & 1.99 & -2.16 & .014 \\
\hline Motivational domain & 6.05 & 2.30 & 2.36 & .001 \\
\hline Cognitive domain & 6.20 & 1.80 & 3.81 & $<.001$ \\
\hline Reconstructive attitude & 4.38 & 1.68 & -6.56 & $<.001$ \\
\hline Creative attitude & 6.12 & 2.41 & 2.55 & .006 \\
\hline
\end{tabular}

Note. TMS - Standard Progressive Matrices (in Polish: Test Matryc w wersji Standard). 
Table 2

Personality features in creative attitudes, with respect to scores in intelligence test

\begin{tabular}{lccccccc}
\hline & \multicolumn{3}{c}{$\begin{array}{c}\text { High intelligence } \\
(n=61)\end{array}$} & \multicolumn{3}{c}{$\begin{array}{c}\text { Average intelligence } \\
(n=36)\end{array}$} & \multicolumn{3}{c}{ Independent samples $t$-test } \\
\cline { 2 - 8 } & $M$ & $S D$ & $M$ & $S D$ & $t$ & $d f$ & $p$ \\
\hline Conformism & 5.18 & 1.85 & 5.50 & 1.65 & 1.34 & 95 & .185 \\
Nonconformism & 5.92 & 2.34 & 5.14 & 2.36 & -2.60 & 95 & .011 \\
Heuristic behaviours & 6.36 & 2.18 & 5.64 & 2.31 & -2.58 & 95 & .011 \\
Algorithmic behaviours & 5.06 & 1.99 & 5.33 & 2.14 & 1.03 & 95 & .305 \\
Motivational domain & 6.05 & 2.30 & 5.14 & 2.22 & -3.14 & 95 & .002 \\
Cognitive domain & 6.20 & 1.80 & 5.58 & 1.73 & -2.65 & 95 & .009 \\
Reconstructive attitude & 4.38 & 1.68 & 4.61 & 1.63 & 1.04 & 95 & .303 \\
Creative attitude & 6.12 & 2.41 & 5.33 & 2.44 & -2.55 & 95 & .012 \\
\hline
\end{tabular}

Table 3

Personality features in creative attitudes, with respect to creativity levels

\begin{tabular}{lccccccc}
\hline & \multicolumn{2}{c}{$\begin{array}{c}\text { High creativity } \\
(n=51)\end{array}$} & \multicolumn{2}{c}{$\begin{array}{c}\text { Average creativity } \\
(n=46)\end{array}$} & \multicolumn{3}{c}{ Independent samples $t$-test } \\
\cline { 2 - 9 } & $M$ & $S D$ & $M$ & $S D$ & $t$ & $d f$ & $p$ \\
\hline Conformism & 5.39 & 2.00 & 4.93 & 1.65 & -1.22 & 95 & .226 \\
Nonconformism & 6.04 & 2.27 & 5.78 & 2.42 & -0.54 & 95 & .591 \\
Heuristic behaviours & 6.35 & 2.12 & 6.37 & 2.27 & 0.04 & 95 & .970 \\
Algorithmic behaviours & 5.04 & 2.09 & 5.09 & 1.91 & 0.12 & 95 & .907 \\
Motivational domain & 5.94 & 2.30 & 6.17 & 2.31 & 0.50 & 95 & .621 \\
Cognitive domain & 6.24 & 1.80 & 6.15 & 1.83 & -0.23 & 95 & .822 \\
Reconstructive attitude & 4.51 & 1.75 & 4.24 & 1.61 & -0.91 & 95 & .431 \\
Creative attitude & 6.10 & 2.49 & 6.15 & 2.35 & 0.11 & 95 & .913 \\
\hline
\end{tabular}

intelligence than those who had not qualified and to find out how the creative attitude personality features differentiate them (Table 4).

The chosen qualification criteria mainly assumed that they would score high or higher than average on a general intelligence test. An independent samples $t$-test was performed to verify the hypothesis that students who qualified for further support are characterised by higher creativity. The results suggest that such students were characterised by significantly higher levels of creativity $(t(95)=-3.54$, $p=.001)$. At the same time, they showed higher levels of nonconformity $(t(95)=-2.01, p=.024)$ in the motivational domain, but no differences were observed for conformity. In the cognitive domain they would choose to use heuristic actions more frequently $(t(95)=-1.45, p=.076)$. No significant differences were observed between the general reproductive and creative attitude, but a statistical trend exhibiting a creative attitude was observed in the students who qualified $(t(95)=-1.81, p=.074)$.

\section{DISCUSSION AND CONCLUSIONS}

Research carried out in Polish schools suggests that high intelligence and above average academic achievements (expressed in terms of grades) (Ćwiok, 2000; Gajda, 2015), together with a lack of behavioural problems, are still the main indicators for identification of gifted students. A student assessed as gifted and exemplary is successful, has a positive attitude towards rules, is open to new things, is hard working (Tokarz \& Słabosz, 2001), learns quickly and effectively and has excellent achievements in the socially valuable domain of activity (Tyszkowa, 1990). Our results show that students scoring high in general intelligence tests are indeed assessed as gifted.

Research analysing the ability of teachers to identify the signs of creativity among students indicates that teachers have difficulties identifying creative students (Gralewski \& Karwowski, 2013; Matrič \& Duh, 2015) due to, amongst other reasons, the fact that students do not always have the opportunity or 
Creative attitude in a group of gifted youths

Table 4

Comparison of the mean scores of the samples of students qualified and not qualified for the "Zdolni z Pomorza" programme

\begin{tabular}{lrrrrrrr}
\hline & \multicolumn{2}{c}{$\begin{array}{c}\text { Qualified } \\
(n=32)\end{array}$} & \multicolumn{2}{c}{$\begin{array}{c}\text { Not qualified } \\
(n=65)\end{array}$} & \multicolumn{2}{c}{ Independent samples $t$-test } \\
\cline { 2 - 8 } & $M$ & $S D$ & $M$ & $S D$ & $t$ & $d f$ & $p$ \\
\hline TMS Raven & 82.25 & 17.33 & 97.86 & 3.67 & -5.04 & 95 & $<.001$ \\
APIS-P & 5.81 & 1.67 & 8.58 & 1.03 & -8.60 & 95 & $<.001$ \\
TCT-DP & 6.63 & 1.88 & 7.97 & 1.70 & -3.54 & 95 & .001 \\
Conformism & 5.19 & 1.38 & 5.17 & 2.05 & 0.05 & 95 & .482 \\
Nonconformism & 5.25 & 2.58 & 6.25 & 2.15 & -2.01 & 95 & .024 \\
Heuristic behaviours & 5.91 & 2.53 & 6.58 & 1.97 & -1.45 & 95 & .076 \\
Algorithmic behaviours & 5.13 & 2.18 & 5.03 & 1.91 & 0.22 & 95 & .414 \\
Motivational domain & 5.34 & 2.43 & 6.40 & 2.16 & -2.17 & 95 & .017 \\
Cognitive domain & 5.72 & 1.85 & 6.43 & 1.74 & -1.85 & 95 & .034 \\
Reconstructive attitude & 4.34 & 1.52 & 4.40 & 1.77 & -0.15 & 95 & .439 \\
Creative attitude & 5.50 & 2.68 & 6.43 & 2.23 & -1.81 & 95 & .074 \\
\hline
\end{tabular}

Note. TMS - Standard Progressive Matrices (in Polish: Test Matryc w wersji Standard).

the will to show signs of such skills at school (Morgan, Latham, \& Shifflet, 2009). Some features regarded by teachers as indicative of a 'bad' student are also characteristic of creativity, which is why such students can be overlooked in the process of nomination (Limont, 2012). In setting out to perform this study, however, we envisaged that teachers who would have had first received training in recognising creativity would use their newfound knowledge when nominating students for the gifted group. Our results confirmed this assumption, as it was revealed that the nominated students were characterised by significantly higher levels of creativity, in comparison to the general population. This is in line with previous research, according to which teachers can acquire the competences needed to identify creativity (Morgan et al., 2009; Jurisevic, 2011, after: Matrič \& Duh, 2015), which suggests the importance of highlighting the need to train teachers in this area.

The results also revealed that students identified by teachers as gifted were characterised by higher indices of creative attitude in the cognitive domain, which define one's intellectual disposition and sensitivity, perceptiveness, as well as memorising, processing and producing new information. They exhibit significantly more heuristic type behaviours, including independent observations, creative imagination, logical memory, divergent thinking, both reconstructive and independent learning, learning through understanding, intellectual elasticity, cognitive activity and reflectiveness - which is in line with previous research on mathematically gifted students (cf. Miller, 1990; Chamberlin \& Moon, 2005). Above average re- sults were also observed in the motivational sphere, defined as a set of characterological features ensuring the active fulfilment of the potential cognitive possibilities of an individual, but with no significant differences between the conforming and nonconforming behaviours. It can be concluded that teachers appreciate the motivation of students to undertake additional activities, but they do not concentrate on nonconformist behaviours (independence, adaptational elasticity, originality, spontaneity, self-criticism), because these features may cause more behavioural and adaptational problems, undesirable to teachers (Siekańska, 2013).

In agreement with the model of giftedness that served as a basis for this study, the criteria for students to qualify for further developmental support included high intellectual potential, increased levels of creativity and motivation to undertake additional activities. All these elements were confirmed by the study results. Students who eventually qualified for further support were additionally characterised by higher results in the characterological creative attitude. In contrast to the group nominated by teachers, they exhibited more variability in the motivational domain, scoring higher in terms of nonconformity, and in the cognitive domain they more frequently chose heuristic behaviours. The goal of providing further support to the students is to encourage them to undertake innovative activities in a chosen field, which is why features defining a creative attitude, such as heuristic and nonconformist behaviours, are highly valued. The fact that higher levels of these features were observed in the group of qualified 
students leads us to the conclusion that the criteria developed for identifying giftedness are appropriate.

Analysis of the literature on the topic, as well as this current research, allows one to estimate that about $2-3 \%$ of the population are characterised by exceptional talent (Renzulli, 2005), and about $13 \%$ of the population qualify as very talented (Foryś, 2014; Freeman, 2010; Limont, 2012). In order to decrease the chance of failing to identify and include in additional programmes students who are gifted, but who have difficulties (Dyrda, 2000; Reis \& McCoach, 2000; Rimm, 2000), as well as to avoid excessive inclusion of students in the gifted group due to only analysing test results (Callahan et al., 2013) and school achievements (McBee, Peters, \& Waterman, 2014), it is worthwhile suggesting to teachers a procedure of identification of talents that involves not only psychometric criteria (results of standardised tests) but also teachers' nominations, analyses of students' creations and their interest in a given topic. One should not underestimate the importance of raising teachers' sensitivity to creativity, which is grounded in this study's results.

\section{ENDNOTES}

1 Pomorskie - dobry kurs na edukację. Wspieranie uczniów o szczególnych predyspozycjach w zakresie matematyki, fizyki i informatyki [Pomeranian region - a good direction for education. Supporting students with particular predispositions for mathematics, physics and informatics].

\section{REFERENCES}

Amabile, T. (1996). Creativity in context. Boulder-Oxford: Westview Press.

Bernacka, R. E., \& Misiuda-Kolejko, E. (2008). Uczniowie zdolni nonkonformistyczni i konformistyczni a ich obraz siebie [Conforming and nonconforming gifted students and their self-image]. In W. Limont, J. Cieślikowska, \& J. Dreszer (eds.), Zdolności. Talent. Twórczość [Giftedness. Talent. Creativity] (pp. 163-177). Toruń: Wydawnictwo Naukowe UMK.

Bernacka, R. E. (2008). Konformizm i nonkonformizm jako osobowościowy mechanizm asekurujący osiągnięcia ucznia uzdolnionego [Conformism and nonconformism as personality mechanisms safeguarding the achievements of a gifted student]. In J. Łaszczyk \& M. Jabłonkowska (eds.), Uczeń zdolny wyzwaniem dla wspótczesnej edukacji [The gifted student as a challenge for present-day education] (pp. 15-22). Warszawa: Wydawnictwo Akademii Pedagogiki Specjalnej.

Bicknell, B. (2009). Who are the Mathematically Gifted? Student, Parent and Teacher Perspectives. Journal of the Korea Society of Mathematical Edu- cation Series D: Research in Mathematical Education, 13, 63-73.

Callahan, C. M., Moon, T. R., \& Oh, S. (2013). Status of middle school gifted programs. Charlottesville: University of Virginia, The National Research Center on the Gifted and Talented. Retrieved from: http://www.nagc.org/resources-publications/ resources-university- professionals.

Chamberlin, S. A., \& Moon, S. N. (2005). Model-Eliciting Activities as a Tool to Develop and Identify Creatively Gifted Mathematicians. The Journal of Secondary Gifted Education, 17, 37-47.

Cieślikowska, J. (2008). Miejsce nauczyciela w systemie edukacji uczniów zdolnych - na podstawie koncepcji i praktycznych rozwiązań Josepha Renzulliego [The place of the teacher in the system of education of gifted students - based on the conceptions and practical solutions of Joseph Renzuelli]. In W. Limont, J. Cieślikowska, \& J. Dreszer (eds.), Zdolności. Talent. Twórczość [Giftedness. Talent. Creativity] (pp. 27-38). Toruń: Wydawnictwo Naukowe UMK.

Csikszentmihalyi, M. (1996). Przeptyw. Jak poprawić sobie jakość życia. Psychologia optymalnego doświadczenia [Flow. How to increase your quality of life. The psychology of optimal experience]. Warszawa: Studio EMKA.

Csikszentmihalyi, M., \& Robinson, R. E. (1990). The Art of Seeing: An Interpretation of the Aesthetic Encounter (pp. 32-33). Malibu, CA: Getty Publications.

Ćwiok, E. (2000). Nieadekwatne osiągnięcia szkolne wybitnie inteligentnych uczniów liceów ogólnokształcących [Exceptionally intelligent secondary school students with inadequate academic achievements]. Psychologia Rozwojowa, 5, 227-246.

Deary, I. J., Strand, S., Smith, P., \& Fernandes, C. (2007). Intelligence and educational achievement. Inteligence, 35, 13-21.

Diezmann, C. M., \& Watters, J. J. (2000). Characteristics of young gifted children. Educating Young Children, 6, 41-42.

Dyrda, B. (2000). Syndrom Nieadekwatnych Osiagnięć jako niepowodzenie szkolne uczniów zdolnych. Diagnoza i terapia [Inadequate Achievements Syndrome as school failure of gifted students. Diagnosis and therapy]. Kraków: Oficyna Wydawnicza Impuls.

Foryś, M. (2014). Metody diagnozowania uczniów [Methods of diagnosing students]. In M. Czarnocka, M. Foryś, \& K. Truś (eds.). Rozpoznać, wspierać, rozwijać [Recognise, support, develop] (pp. 8-14). Warszawa: ORE.

Freeman, J. (2010). Gifted Lives. What happenes when gifted children grow up. London: Routledge.

Freiman, V. (2006). Problems to discover and to boost mathematical talent in early grades: a challenging situations approach. The Montana Mathematics Enthusiast, 3, 51-75. 
Gajda, A. (2015). Osiągnięcia szkolne i kreatywność - w poszukiwaniu przyczyn zróżnicowania relacji [School achievements and creativity - in search of the causes of the variability in this relationship]. Teraźniejszość - Człowiek - Edukacja, 18, 55-78.

Gardner, H. (1983). Frames of mind: The theory of multiple intelligences. New York: Basics Books.

Gardner, H. (2002). Inteligencje wielorakie. Teoria $w$ praktyce [Multiple intelligences. A theory in practice]. Poznań: Media Rodzina.

Gottfried, A. W., Gottfried, A. E., Bathurst, K., \& Guerin, D. W. (1994). Gifted IQ: Early developmental aspects. The Fullerton Longitudinal Study. New York: Plenum Press.

Gottfried, A. W., Gottfried, A. E., Cook, C. R., \& Morris, P. E. (2005). Educational characteristics of adolescents with gifted academic intrinsic motivation: A longitudinal investigation from school entry through early adulthood. Gifted Child Quarterly, 49, 172-186.

Gralewski, J., \& Karwowski, M. (2013). Threshold hypothesis: Fact or Artifact? Thinking Skills and Creativity, 8, 25-33.

Guilford, J. P. (1978). Natura inteligencji czlowieka [The nature of human intelligence]. Warszawa: PWN.

Kaufman, S. B., \& Sternberg, R. J. (2008). Conceptions of giftedness. In S. Pfeiffer (ed.), Handbook of giftedness in children: Psychoeducational theory, research, and best practices (pp. 71-91). New York, NY: Plenum.

Ledzińska, M. (2010). Przeszkody w rozwoju zdolności - refleksja psychologa [Barriers to the development of talents - a psychologist's reflection]. In W. Limont, J. Dreszer, \& J. Cieślikowska (eds.), Osobowościowe $i$ środowiskowe uwarunkowania rozwoju ucznia zdolnego [Personality and the environmental conditions of a gifted student's development] (pp. 51-66). Toruń: Wydawnictwo Naukowe UMK.

Lewis, G. (1998). Jak wychować utalentowane dziecko [How to raise a gifted child]. Poznań: Rebis.

Limont, W. (2012). Uczeń zdolny. Jak go rozpoznać i jak z nim pracować [Gifted students. How to recognise and work with them]. Sopot: GWP.

Lohman, D. F. (2005). An aptitude perspective on talent: Implications for identification of academically gifted minority students. Journal for the Education of the Gifted, 28, 333-360. DOI: 10.4219/ jeg-2005-341

Maslow, A. H. (1983). Postawa twórcza [Creative attitude]. Nowiny Psychologiczne, 8-9, 58-71.

Matczak, A., Jaworowska, A., Ciechanowska, A., Stańczak, J., \& Zalewska, E. (2005). Bateria Testów APIS-P(R). Podręcznik [The APIS-P(R) Battery of Tests. A Handbook]. Warszawa: Pracownia Testów Psychologicznych PTP.
Matczak, A., Jaworowska, A., \& Stańczak, J. (2000). Rysunkowy Test Twórczego Myślenia TCT-DP. Podręcznik [The Test for Creative Thinking - Drawing Production TCT-DP. A Handbook]. Warszawa: Pracownia Testów Psychologicznych PTP.

Matrič, M., \& Duh, M. (2015). Creativity Among Gifted and Non-Gifted Students. The New Educational Review, 40, 247-259.

McBee, M. S., Peters, S. J., \& Waterman, C. (2014). Combining scores in multiple-criteria assessment systems: The impact of combination rule. Gifted Child Quarterly, 58, 69-89.

Miller, R. (1990). Discovering Mathematical Talent. ERIC Digest. Retrieved from http://eric.ed.gov /?id=ED321487.

Morgan, V., Latham, N., \& Shifflet, R. (2009). Teachers' Ability to Identify Divergent Thinking in Their Students. Gifted Children, 3, 5-9.

Mönks, F. J. (1990). Poradnictwo i wspieranie szczególnie zdolnych uczniów [Counselling and supporting especially gifted students]. Lublin: Annales UMCS.

Mönks, F. J. (2008). Identification and education of the gifted learner. In J. Łaszczyk \& M. Jabłonowska (eds.). Uczeń zdolny wyzwaniem dla wspótczesnej edukacji [Gifted Student as a Challenge for Contemporary Education] (pp. 79-85). Warszawa: Wydawnictwo Akademii Pedagogiki Specjalnej.

Mumford, M. D., Scott, G. M., Gaddis, B., \& Strange, J. M. (2002). Leading creativepeople: Orchestrating expertise and relationships. The Leadership Quarterly, 13, 705-750.

Nęcka, E. (2002). Psychologia twórczości [The psychology of creativity]. Gdańsk: GWP.

Nęcka, E. (2003). Inteligencja: geneza - struktura - funkcje [Intelligence: genesis-structure-functions]. Gdańsk: GWP.

Pfeiffer, S. I. (2012). Current perspectives on the identification and assessment of gifted students. Journal of Psychoeducational Assessment, 30, 3-9. DOI: 10.1177/0734282911428192

Popek, S. (2001). Człowiek jako jednostka twórcza [Humans as creative entities]. Lublin: Wydawnictwo UMCS.

Popek, S. (2008). Kwestionariusz Twórczego Zachowania $K A N H$ [The KANH questionnaire of creative behaviour]. Lublin: Wydawnictwo UMCS.

Reis, S. M., \& McCoach, D. B. (2000). The underachievement of gifted students: What do we know and where do we go? Gifted Child Quarterly, 44, 152-170. DOI: 10.1177/001698620004400302

Renzulli, J. S. (1978). What makes giftedness? Re-examining a definition. Phi Delta Kappan, 60, 180-184.

Renzulli, J. S. (2005). The three-ring definition of giftedness: A developmental model for promoting creative productivity. In R. J. Sternberg \& J. E. Davidson (eds.), Conceptions of giftedness (pp. 246-280). New York: Cambridge University Press. 
Renzulli, J. S., \& Reiss, S. M. (2000). The schoolwide enrichment model. In K. A. Heller, F. J. Monks, R. J. Sternberg, \& R. F. Subotnik (eds.), International handbook of giftedness and talent (pp. 367-382). Oxford: Elsevier Science Ltd.

Rimm S. (2000). Dlaczego zdolne dzieci nie radza sobie $w$ szkole [Why gifted students do not perform at school]. Poznań: Wydawnictwo Moderski i S-ka.

Rinn, A., \& Plucker, J. (2004). We recruit them, but then what? The educational and psychological experiences of academically talented undergraduates. Gifted Child Quarterly, 48, 54-67.

Rinn, A. N. (2012). Implications for addressing the psychosocial needs of gifted individuals: A response to Subotnik, Olszewski-Kubilius, and Worrell (2011). Gifted Child Quarterly, 56, 206-209. DOI: $10.1177 / 0016986212456076$

Saha, B. (2012). Creativity in relation to socio-economic status in secondary school students. West Bengal, Indian Journal of Applied Research, 2, 60-61.

Saricam, H., \& Ogurlu, U. (2015). Metacognitive awareness and math anxiety in gifted students. Cypriot Journal of Educational Science, 10, 338-348.

Sękowski, A. E. (2013). Inteligencja, twórczość, mądrość a wybitne zdolności [Intelligence, creativity, wisdom and exceptional talents]. In A. E. Sękowski (ed.), Psychologia zdolności. Wspótczesne kierunki badań [The psychology of giftedness. Directions of current research] (pp. 173-192). Warszawa: Wydawnictwo Naukowe PWN.

Siekańska, M., \& Sękowski, A. (2008). Job Satisfaction and Temperament Structure of Gifted People. Mensa Research Journal, 39, 34-40.

Siekańska, M. (2013). Koncepcje zdolności a identyfikacja uczniów zdolnych [Conceptions of giftedness and identifying talented students]. In A. E. Sękowski (ed.), Psychologia zdolności. Wspótczesne kierunki badań [The Psychology of giftedness. Directions of current research] (pp. 115-124). Warszawa: Wydawnictwo Naukowe PWN.

Sokol, A., Gozdek, A., \& Figurska, I. (2015). The importance of teacher leadership in shaping the creative attitudes of students. Procedia - Social and Behavioral Sciences, 197, 1976-1982.

Sternberg, R. J. \& Davidson, J. (eds.). (2005). Conceptions of giftedness ( ${ }^{\text {nd }}$ ed.). New York: Cambridge University Press.

Strzałecki, A. (2003). Psychologia twórczości. Między tradycja a ponowoczesnościa [The psychology of creativity. Between tradition and post-modernism]. Warszawa: Wydawnictwo Uniwersytetu Kardynała Stefana Wyszyńskiego.

Subotnik, R. F., Olszewski-Kubilius, P., \& Worrell, F. C. (2011). Rethinking giftedness and gifted education: A proposed direction forward based on psychological science. Psychological Science in the Public Interest, 12, 3-54. DOI: 10.1177/1529100611418056

Szymanski, T., \& Shaff, T. (2013). Teacher Perspectives Regarding Gifted Diverse Students. Gifted Chil- dren, 6, Article 1. Available at: http://docs.lib.purdue.edu/giftedchildren/vol6/iss1/1.

Tannenbaum, A. J. (2003). Nature and nurture of giftedness. In N. Colangelo \& G. A. Davis (eds.), Handbook of gifted education (pp. 45-59). Boston: Pearson Education, Inc.

Tokarz, A., \& Słabosz, A. (2001). Cechy uczniów preferowane przez nauczycieli jako wymiar aktywności twórczej w szkole. Cz. II. Uczeń idealny i twórczy w preferencjach badanych nauczycieli. [Features of students that are preferred by teachers as a dimension of creative activity at school. Part II. The perfect and the creative student in the preferences of studied teachers]. Edukacja. Studia. Badania. Innowacje, 3, 36-18.

Tokarz, A. (2005). Procesy motywacyjne a dyspozycje do wybitnych osiągnięć w kontekście rozwoju. [Motivational processes and predispositions towards excellent school achievements in the context of development]. In W. Limont, \& A. Cieślikowska (eds.), Wybrane zagadnienia edukacji uczniów zdolnych, Tom II. Uczeń - Nauczyciel Edukacja [Selected Issues of Gifted Students Education, Vol. II. Student - Teacher - Education] (pp. 35-59). Kraków: Impuls.

Tortop, H. S. (2015). A comparison of gifted and non-gifted students' self-regulation skills for science learning. Journal for the Education of Gifted Young Scientists, 3, 42-57.

Turska, D. (ed.). Twórczość w teorii i praktyce [Creativity in theory and in practice]. Lublin: Wydawnictwo UMCS.

Tyszkowa, M. (1990). Aktywność i dziatalność dzieci i mtodzieży [Activity of children and youths]. Warszawa: Wydawnictwa Szkolne i Pedagogiczne.

Wieczerkowski, W., Cropley, A. J., \& Prado, T. M. (2000). Nurturing talents/gifts in mathematics. In K. A. Heller, F. J. Monks, R. J. Sternberg, \& R. F. Subotnik (eds.), International handbook of giftedness and talent (pp. 413-425). Oxford: Elsevier Sciences Ltd.

Worrell, F. C., Olszewski-Kubilius, P., \& Subotnik, R. F. (2012). Important issues, some rhetoric, and a few straw men: A response to comments on "rethinking giftedness and gifted education". Gifted Child Quarterly, 56, 224-231. DOI: 10.1177/0016986212456080

Ziegler, A., \& Heller, K. A. (2000). Conceptions of giftedness: A meta-theoretical perspective. In K. A. Heller, F. J. Mönks, R. Sternberg, \& R. Subotnik (eds.), International handbook of giftedness and talent (pp. 3-22). Oxford, UK: Pergamon. 